\title{
ENKRIPSI 472319 HAHSLM DALAM BILANGAN SEGITIGA DI ERA EKONOMI COVID
}

\author{
R Mochamad A \\ Universitas Islam Negeri Syarif Hidayatullah Jakarta \\ Email: hs.dynivi@gmail.com
}

\begin{abstract}
ABSTRAK
Tujuan riset ini adalah untuk menganalisis bilangan segitiga yang menyimpan enkripsi digital root 472319 sesuai HAHSLM era ekonomi Covid. Penjumlahan bilangan segitiga membentuk anak tanngga yang mendaki mulai dari 1,2,3 sampai tidak berhingga. Aritmatika deret bilangan dari angka berurut membentuk penjumlahan yang semakin besar. Obyek riset ini yaitu bilangan bulat positif dimulai dari angka 1,2,3 sampat tidak berhingga. Riset dikerjakan dengan cara deskriptif aritmatis. Metode yang dipakai adalah similaritas, refleksivitas, dan dynivitas dalam rumus H4. Hasil yang didapatkan yaitu deret hitung bilangan membentuk deret ukur aritmatika yang semakin besar jumlahnya. Bilangan dijumlahkan dalam formasi tangga dengan deret $1+2+3+4+5$ dan seterusnya sampai tidak berhingga. Akumulasi bilangan segitiga menyimpan pengulangan himpunan bilangan dalam digital root. Akar bilangan 319, 913, 616 merupakan tiga kelompok bilangan yang memiliki similaritas dengan refleksivitas dari hahslm 7 pada himpunan bilangan 616 berupa representasi 1 dan 6 . Refleksivitas rumus H pada 2319 tercermin pada dua himpunan bilangan 319 dan 913, Dynivitas digital root pada bilangan segitiga sesuai dengan Quran Surat Al-Hijr [15]: 87 yang berisi Tujuh dan Quran, berupa bilangan 7 dan 2319 dari faktorisasi 114 surat. Quran dapat dijadikan solusi dalam era ekonomi Covid.
\end{abstract}

Kata kunci: HAHSLM, 472319, Bilangan segitiga, Quran.

\begin{abstract}
The purpose of this research is to analyze the triangular number that stores the digital root encryption 472319 according to the Covid economic era Hahslm. The sum of the triangles forms a child with no ascending from 1,2,3 to infinity. Arithmetic series of numbers from consecutive numbers forms an increasingly larger addition. The object of this research is a positive integer starting from the number 1,2,3 to infinity. The research was carried out in a descriptive arithmetic manner. The methodology used is similarity, reflexivity, and dynivity in the $\mathrm{H} 4$ formula. The results obtained are the arithmetic series of numbers forming an arithmetic measurement series that is getting bigger in number. The numbers are added in a ladder formation with the sequence $1+2+3+4+5$ and so on until they are infinite. The accumulation of triangular numbers stores the repetition of the set of numbers in the digital root. The roots of numbers $319,913,616$ are three groups of numbers that have similarity to the reflexivity of page 7 in the set of numbers 616 in the form of representations of 1 and 6. The reflectivity of the formula $\mathrm{H}$ in 2319 is
\end{abstract}


reflected in the two sets of numbers 319 and 913. with the Quran Surat Al-Hijr [15]: 87 which contains Seven and the Quran, in the form of numbers 7 and 2319 from the factorization of 114 letters. The Quran can be used as a solution in the Covid economic era.

Keywords: HAHSLM, 472319, Triangular number, Quran.

\section{PENDAHULUAN}

Angka sudah dipergunakan sejak jaman dahulu dan Aljabar yang dikembangkan oleh pemikir Islam terdahulu sebagai ilmu tentang angka sudah dikenal sejak lama. Untuk menggambarkan bahwa angka yang ada dari dulu hingga sekarang sampai yang akan datang senantiasa menuju pada titik sang Pencipta, maka penjelasan di bawah ini lebih banyak tulisan angka-angka dibandingkan dengan kata atau kalimat. Hal ini disebabkan bahwa penggunaan angka akan lebih sederhana serta mudah dipahami dibandingkan dengan uraian kata atau kalimat. Tetapi untuk beberapa angka yang khusus, tentunya akan diberi sedikit keterangan untuk menghindari penafsiran yang berbeda dengan maksud yang hendak disampaikan.

Risalah Islam merupakan risalah yang berpijak pada kenyataan obyektif manusia dengan fitrah yang dimiliki oleh manusia. Karena itu manusia dituntut untuk memiliki kemampuan mengungkap hikmah Risalah Islam yang terkandung dalam al-Quran maupun as-Sunnah.

Pada bab sebelumnya telah diterangkan bahwa dalam kata Iqro' tersirat makna Islam. Bukan suatu hal yang berlebihan bila ternyata di dalam ayat-ayat berikutnya pun mengandung makna Islam pula. Firman Allah yang pertama ini yang disampaikan lewat perantaraan malaikat Jibril kepada nabi Muhammad Saw., terdiri dari 5 ayat.
Ayat yang pertama QS. Al-Alaq [96]: 1 berbunyi: "Iqro' bismi rabbikal ladzi kholaq", yang artinya: "Bacalah dengan nama Tuhanmu yang telah menciptakanmu". Penjelasan dari ayat pertama ini akan dijabarkan pada kesempatan lain, karena makna yang terkandung di dalamnya sangat luas. Salah satunya adalah di semua aspek kehidupan sehari-hari umat Islam diperintahkan untuk membaca ayat-ayat Allah sebagai bukti bahwa Allah Swt.-lah yang menciptakan manusia. Dan bacaan yang memang sering dan pasti diucapkan oleh umat Muslim adalah surat pembuka al-Quran yaitu surat al-Fatihah. Bila untuk menjelaskan ayat pertama surat Iqra' ini, perlu menerangkan surat al-Fatihah yang mempunyai segudang makna, maka tidak cukuplah halaman buku ini untuk menjelaskan kandungan isinya. Untuk itu akan diberikan ruang khusus sebagai penjabaran hal-hal yang berkaitan dengan ayat pertama al-Alaq dan al-Fatihah ini pada kesempatan lain. Begitu juga dengan ayat-ayat ganjil lainnya pada wahyu pertama ini, yang berarti semoga penjelasan ayat ke-1, ke-3, dan ke-5 dapat dirangkum lebih mendalam pada penjelasan buku lain. Sehingga pada bahasan kali ini lebih menitikberatkan pada kajian ayat genapnya yaitu ayat ke- 2 dan ayat ke-4.

Di bab ini akan dikutip dua ayat yang berhubungan dengan judul buku ini yaitu ayat kedua dan keempat yang 
mengandung kata-kata penuh hikmah seperti alaq dan qolam. Pada ayat yang kedua, berbunyi: "Kholaqol insana min alaq", yang artinya: "Yang telah menciptakan manusia dari segumpal darah". Penjelasan ayat ini akan lebih mudah dicerna jika sudah mendapatkan maksud dari ayat yang keempat, berbunyi: "Alladzi 'allama bil qolam", yang artinya: "Yang telah mengajarkan dengan pena".

Hubungan antara ayat keempat dengan uraian berikut ini ada pada kata pena. Yang dimulai dari pengetahuan umum bahwa, periode kedatangan Islam dimulai di jazirah Arab. Wilayah indah bergurun ini memiliki beragam budaya. Salah satu aktivitas yang berkembang dengan subur adalah kebiasaan berkomunikasi secara lisan berupa pembacaan syair, puisi, prosa, atau sajak. Budaya ini mencapai tingkat kesempurnaannya dengan adanya bukti pemberian penghargaan tertinggi kepada pencipta syair terbaik. Penghargaan yang paling membanggakan para seniman adalah pemajangan hasil karya seni di dinding Kabah. Sehingga hasil karya seni tersebut dapat diketahui oleh setiap kafilah yang mengunjungi Kabah dalam rangka berdagang atau beribadah. Budaya lisan ini berkembang pesat disebabkan oleh sifat bangsa Arab yang cenderung nomaden atau berpindah-pindah untuk melakukan perdagangan serta aktivitas kehidupan lainnya. Pertemuan dengan beragam budaya antar bangsa, perdagangan, maupun ibadah adalah sebagian kecil kegiatan yang sangat mengandalkan komunikasi lisan, sementara kemampuan menulis pun berkembang cukup baik walaupun tidak sepesat budaya lisan. Sebagai salah satu buktinya adalah penulisan syair yang dilantunkan atas dasar hafalan-hafalan para pembuat syair yang kemudian ditempelkan pada dinding Kabah. Perkembangan budaya membaca dan menulis bangsa Arab mencapai masa keemasan dipicu oleh perkembangan agama Islam. Islam mengajarkan umatnya untuk menguasai kemampuan baca tulis. Hal ini diajarkan semenjak Allah berfirman pada wahyu pertama-Nya agar manusia meningkatkan kemampuan dalam kaitannya dengan pena, yaitu kemampuan baca tulis.

Hubungan antara ayat pena dengan kegiatan tulis menulis. Pena identik dengan tulis menulis, dan pena sejak jaman Nabi dipakai untuk menulis apa saja, tentunya dengan menggunakan tangan kanan (bagi yang kidal, berarti dengan tangan kiri). Pada jaman sekarang ini yang dikenal dengan era informasi dan komunikasi, bisa memanfaatkan kemajuan teknologi untuk menulis di komputer atau menggunakan mesin tik tidak dengan tangan kanan saja tetapi dengan kedua tangan baik kiri maupun kanan. Tetapi ketika kembali memakai pena untuk menulis, maka kembali memegangnya dengan tangan kanan. Memang ada sebagian kecil yang memiliki sifat kidal akan memegang pena dengan tangan kiri.

Aktivitas menulis ini memiliki tiga bagian utama yang terdiri dari pena sebagai alat tulis, tangan yang befungsi untuk menggerakkan, dan tulisan yang merupakan hasil dari goresan pena dari gerakan tangan. Fungsi tangan sebagai penggerak dalam hal ini menjadi faktor yang dominan, karena tanpa tangan maka tidak akan terjadi pertemuan antara pena 
dan tulisan. Walaupun pena, tangan, dan tulisan memiliki fungsi masing-masing, tetapi dari penjelasan ini tangan menjadi hal yang paling penting untuk diuraikan.

Tangan yang normal memiliki lima jari yang terdiri dari kelingking, jari manis, jari tengah, telunjuk, dan jempol. Dalam kesehariannya jari-jari ini memiliki keunikannya sendiri-sendiri. Salah satu kegiatan manusia yang bergantung pada ciri khas jari-jari ini serta mengandalkan kemampuan permainan jari adalah bermain piano. Kepiawaian seseorang dalam membunyikan tuts-tuts piano secara sendiri, terpisah, atau bersamaan dilandasi atas kekuatan dan keunikan jari-jari serta kemampuan mengatur pilihan jari mana yang menekan tuts, dan jari mana yang tidak.

Wabah pandemi Coronavirus yang terjadi di seluruh negara di dunia dan penyebaran wabah ini telah mempengaruhi berbagai sektor salah satunya di sektor pendidikan secara. Meski, pandemi Coronavirus adalah hal baru, tetapi sudah memiliki efek berbahaya bagi umat manusia. Wabah COVID-19 telah menimbulkan gangguan pendidikan, dan masalah kesehatan global yang terbukti sangat sulit dikelola oleh sistem kesehatan global. Saat ini, tidak ada bangsa atau ras di seluruh dunia yang kebal dari pandemi virus korona, dan seluruh dunia tampaknya kewalahan oleh kecepatan penyebaran dan efek merusak dari COVID-19.

\section{METODE PENELITIAN}

Ruang lingkup penelitian ini adalah menganalisis Matematika, Islam dan Triangular Numbers serta konstanta Roikhan juga Hahslm 472319 dengan
Covid-19 yang berdampak ekonomi global. Dikarenakan penelitian ini mengandung dua unsur yaitu matematika dan Sosial (Islam), maka Penelitian ini menggunakan metode pengumpulan data yang bersifat campuran (Mix Methods). Data kuantitatif dan kualitatif digunakan untuk memperoleh data dengan menggunakan metode penelitian yang bersifat campuran diharapkan dapat memperoleh hasil yang lebih baik di bandingkan menggunakan 1 metode saja. Metode yang digunakan lainnya yaitu Metode penelitian perkembangan yang bertujuan untuk menyelidiki pola-pola urutan pertumbuhan ekonomi atau perubahan ekonomi pada era covid 19 dengan pemodelan matematika sosial.

Metode pengumpulan yang digunakan pada penelitian ini adalah metode dokumentasi, yaitu adalah metode yang menggunakan cara mengumpulkan informasi melalui data-data studi pustaka, eksplorasi literatur-literatur dan juga data yang diambil dari Jurnal. Sedangkan data sekunder yang berbentuk tabel diambil dari web yang melalui analisis yang cocok dengan topik yang di bahas pada penelitian ini.

- Data pengaruh matematika diperoleh dari bagaimana matematika ini dapat berhubungan dengan ilmu lain.

- Data perkembangan umat Islam diperoleh berdasarkan jurnal yang ditulis atas kejadian nyata yang berada di dunia.

- Dengan data yang telah terkumpul itulah, penulis dapat membuat penelitian ini dengan sebaik baiknya berdasarkan data yang relevan dan yang terbaru sehingga nantinya 
penelitian dapat lebih lanjut lebih mudah dipahami.

Penelitian ini menggunakan beberapa variabel yaitu matematika, Sosial, Islam, dan Covid 19 serta rumus Hahslm 472319.

- Membangun kebenaran melalui diskusi yang berasal dari aksioma dan definisi bertepatan merupakan hal-hal yang dilakukan oleh seorang matematikawan

- Setiap individu umat manusia memiliki suatu sifat dasar yang dinamakan sosial

- Suatu ilmu yang berkaitan dengan sumber daya material baik perorangan, masyarakat, dan negara yang bertujuan untuk meningkatkan kesejahteraan disebut dengan ilmu Ekonomi.

- Allah memulai dengan desain ibadah kemudian barulah menyiptakan alam semesta, hingga menurunkan agama kepada Nabi Muhammad Saw sebagai nabi dan rasul terakhir yang dijadikan sebagai panutan manusia menjalani hidup hingga akhir zaman dikenal dengan agama Islam.

\section{HASIL PENELITIAN DAN PEMBA- HASAN}

Ada penelitian yang menjelaskan bahwa triangular numbers merupakan akar bilangan dari bilangan segitiga yang berulang secara teratur dengan urutan 1,3,6,1,6,3,1,9,9,1,3 dan seterusnya secara berulang (xx,2021). Ada juga riset yang mengatakan bahwa bilangan segitiga menjadi aksioma bahwa terdapat math magic dalam matematika dengan adanya pengulangan pada angka 1,3,6,9 (xx,
2021). Studi terdahulu hanya terbatas pada analisis bahwa angka yang sering muncul dari kombinasi bilangan matematika adalah suatu keniscayaan karena adanya hitungan berbasis 10 $(0,1,2,3,4,5,6,7,8,9)(\mathrm{xx}, 20201)$.

Ketidakmampuan logika matematis modern untuk mencari filosofi dari keberadaan triangular number dan math magic sebagai batas kemampuan pengetahuan empiris $(\mathrm{xx}, 2021)$. Bermula dari kombinasi aritmatis kemudian memperoleh triangular numbers dan math magic. Sedangkan matematika Islam memiliki akar filosofi yang lebih konsisten bahwa semua ciptaan Tuhan termasuk bilangan matematis akan membentuk pola ibadah. Hal ini sesuai dengan QS. Al-Isra [17]:44 bahwa benda hidup dan mati termasuk bilangan matematika bertasbih kepada Tuhan.

Dari nomor urut dan akar bilangan yang ada, maka terlihat dengan jelas bahwa terjadi pengulangan pada akar bilangan tersebut. Lagi-lagi akan ditampilkan tabel, kali ini akan ditampilkan yang lebih sederhana lagi untuk memudahkan pembaca yang tidak terbiasa dengan angka-angka.

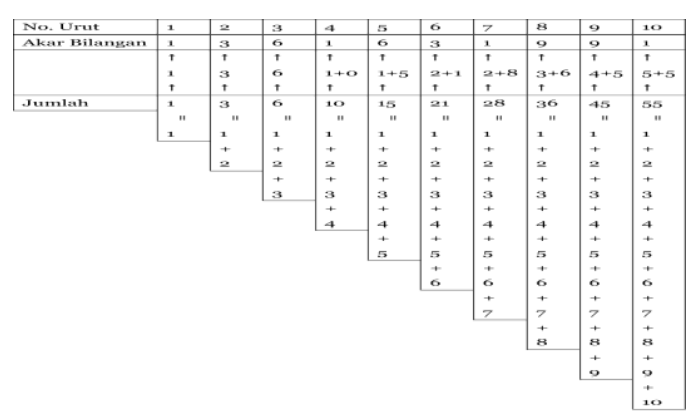

Gambar 1. Tabel Angka Tuhan

Lihat saja intinya, bahwa setiap angka memiliki akar bilangan. Angka- 
angka yang berurutan seperti nomor urut lalu dijumlahkan, juga memiliki akar bilangan. Rangkuman dari penjumlahan berdasarkan angka-angka yang berurut untuk mendapatkan akar bilangannya seperti terlihat dalam tabel berikut.

Tabel 1. Akar Bilangan

\begin{tabular}{|l|l|l|l|l|l|l|l|l|l|l|l|l|l|l|l|l|l|l|}
\hline No Urut & 1 & 2 & 3 & 4 & 5 & 6 & 7 & 8 & 9 & 10 & 11 & 12 & 13 & 14 & 15 & 16 & 17 & 18 \\
\hline Akar Bilangan & 1 & 3 & 6 & 1 & 6 & 3 & 1 & 9 & 9 & 1 & 3 & 6 & 1 & 6 & 3 & 1 & 9 & 9 \\
\hline
\end{tabular}

Jika dikelompokkan menjadi tiga bagian yang masing-masingnya terdiri dari tiga angka, maka terdapat beberapa kemungkinan pola kelompok dalam tiap kelompoknya yang berulang. Salah satu bentuk pola berulang yang dapat dipisahpisahkan adalah:

\section{$\begin{array}{lllllll}13 & 616 & 319 & 913 & 616 & 319 & 9\end{array}$}

Maka tiga kelompok yang sesuai dengan pola berulang yang di tiap kelompok ada tiga angka seperti yang disebutkan di atas adalah

Kelompok I: 319

Kelompok II: 913

Kelompok III: 616

Sekali lagi didapatkan angka yang mengingatkan pada simbol di tangan. Pada kelompok I ada angka 3,1,9 yang persis dengan lambang tangan kiri pada pembahasan sebelumnya bahwa tangan kiri juga menyimpan lambang angka 3,1,9 yang berkaitan dengan surat dan ayat alQuran yaitu surat 3 ayat 19.

Sedangkan pada kelompok II terdapat angka 9,1,3 yang dengan seksama hampir mendekati simbol yang ada pada tangan kanan, yang juga sudah dibahas sebelumnya. Yaitu tangan kanan menyimpan huruf Arab sinlammim. Sehingga jika diperhatikan ada kemiripan pada kelompok II yaitu angka 9,1,3 dengan huruf sinlammim. Bisa saja angka dari kelompok II yaitu 9,1,3 yang dalam bahasa Arab tertulis angka ditransformasikan menjadi huruf yang mendekati bentuk angka ini. Angka 9 ( diganti dengan huruf mim (ح), angka 1 ( ) diganti dengan huruf lam (J), dan angka 3 ( ) diganti dengan huruf sin (w). Selajutnya bila baca huruf-huruf ini dari kanan ke kiri sesuai aturan baca tulis bahasa Arab terbentuk kata sinlammim ( ? لس), yang merupakan akar kata Islam.

Tabel 2. Simbol Angka Dan Huruf Di Tangan Kanan

\begin{tabular}{|c|c|c|c|}
\hline & Mim & Lam & Sin \\
\hline Angka & $q$ & J & $r$ \\
\hline Huruf & $r$ & $J$ & $\omega$ \\
\hline Jari & Jempol & Telunjuk & $\begin{array}{c}\text { Kelingking, } \\
\text { jari manis, } \\
\text { jari tengah }\end{array}$ \\
\hline
\end{tabular}

Secara umum, angka-angka inipun menyatakan ke-Islam-annya, dengan selalu mengulang-ulang angka yang sama dari penjumlahan angka berurut tersebut.

Untuk kelompok III, muncul angka yang tidak tercetak dalam tangan manusia yaitu angka 6,1,6. Sepintas dalam ilmu matematika angka 6,1,6 bisa dikatakan sebagai anggota dari kelompok I (319) dan II (913), dengan cara menjumlahkan pada kelompok I dan II yaitu:

Hitung Penjumlahan

$$
\begin{array}{rrr}
3 & 1 & 9 \\
9 & 1 & 3 \\
\hline 12 & 2 & 12
\end{array}
$$

Kemudian hasil penjumlahan ini, 12,2,12 dibagi dengan bilangan 2 sehingga masing-masing angka menghasilkan angka yang persis dengan kelompok III.

\section{Hitung Pembagian}




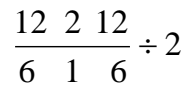

Kemunculan angka 2 sebagai pembagi dari jumlah bilangan kelompok I dan II, juga mengandung makna tersendiri. Dan angka 2 ini bisa dikatakan sebagai bagian dari perhitungan angka Tuhan yang cukup rumit. Secara mudahnya dapat disebutkan bahwa angka dua ini bukan ketidaksengajaan, sehingga tiba-tiba muncul. Memang ada maksud dibalik itu, yang akan dijelaskan pada buku lain. Karena angka dua ini mengandung kerumitan yang sangat tinggi. Banyak aspek yang dapat dihubungkan, sehingga mungkin perlu penjelasan tersendiri secara panjang lebar mengenai hal ini.

Setelah itu, angka 3,1,9 dan angka 9,1,3 (dalam hal ini 9,1,3 dapat diterjemahkan jadi sinlammim) merupakan makna dari ayat al-Quran. Selain 319 dan 913 ada yang ketinggalan yaitu 616. Ternyata 6,1,6 merupakan penjelasan lebih lanjut dari surat Ali Imran [3] ayat 19 ini yang artinya: Sesungguhnya agama di sisi Allah adalah Islam. Asmaul Husna yang dimiliki oleh Allah antara lain:

- Allah

- Ar-Rahman

- Ar-Rahim

- Al-Malik

- Al-Quds

- As-Salam

Pada Asmaul Husna yang ke-6 diperoleh nama indah Allah adalah AsSalam, yang memiliki kata dasar sinlammim. Dengan angka 6 diartikan sebagai Islam, kemudian ternyata angka 6 ini yaitu Islam berada di sebelah kanan dan kirinya angka 1 yang merupakan simbol dari Tuhan Yang Satu. Penjabarannya menjadi: di sisi kiri satu ada Islam, dan di sisi kanan satu ada Islam. Atau bisa dikatakan sebagai: di setiap sisi satu ada Islam. Dapat disimpulkan bahwa angka 6,1,6 menyimpan makna yaitu 'di sisi Allah adalah Islam'.

Bab sebelumnya menyatakan jangan-jangan ada hubungan antara kata salam (42) yang berjumlah 42 kata dalam al-Quran, As-Salam (6) yang merupakan asmaul Husna yang ke-6, dan kata Islam (139) jumlah kata dari kata dasar Sinlammim ada 139 kata dalam al-Quran. Walaupun dijelaskan secara parsial di atas, dapat ditarik kesimpulan bahwa memang betul ke-3 kata itu saling berkait. Selain katanya mengandung akar yang sama yaitu sinlammim, juga bilangan yang menyertainya menunjuk pada angka yang sama. Akar bilangan 42 (salam) yaitu 4+2 sama dengan 6, dimana 6 adalah As-Salam. Begitu juga dengan akar bilangan 139 (Islam) adalah 1+3+9 sama dengan 12, dimana 12 adalah kelipatan dari 6 , yaitu $2 \times 6=12$.

Dari angka kelompok I, II, dan III ternyata kesemuanya bermuara pada ayat al-Quran yang menyimpan kedahsyatan tersebut. Itu baru penjelasan satu ayat. Coba bayangkan, untuk menguraikan makna tersembunyi dari sebuah ayat, diperlukan generasi ber generasi untuk memahaminya. Belum lagi ayat yang lain, belum lagi ini, belum lagi itu, mungkin sampai kapan pun al-Quran tidak akan pernah terungkap oleh manusia.

- Kelompok I: 3,1,9 menyatakan di sisi Allah adalah Islam

- Kelompok II: 9,1,3 menyatakan Islam 
- Kelompok III: 6,1,6 menyatakan di sisi Allah adalah Islam.

Maka terdapat pernyataan yang hendak dikatakan oleh semua angka yang dapat dituliskan di jagat raya ini, bahwa:

"Sesungguhnya agama di sisi Allah adalah Islam."

Kembali pada kemunculan akar bilangan yang memiliki pola berulang seperti dijelaskan sebelumnya. Bahwa dalam akar bilangan yang berulang terdapat angka diantara 1 sampai 9 yang muncul yang tidak sesuai nomor urut. Angka yang muncul terus hanya ada empat angka, terdiri dari 1,3,6, dan 9 . Sedangkan angka yang tidak pernah muncul dalam akar bilangan merupakan sisanya yang berjumlah lima buah antara lain: 2,4,5,7, dan 8. Nol dalam hal ini tidak dimasukkan karena diasumsikan sebagai angka netral.

Mengapa hasil akhir dari penjumlahan angka-angka tersebut berupa akar bilangan hanya ada empat angka? Jika keempat angka ini dijumlahkan, yaitu $1+3+6+9$ akan diperoleh bilangan 19 , dan kembali bilangan 19 ini untuk dicari akar bilangannya dengan menjumlahkan angka-angka di dalamnya sendiri sampai tinggal satu angka yang tersisa yaitu $1+9=10$, lalu $1+0=1$. Kesimpulan yang didapatkan dari hitungan sederhana ini bahwa seluruh angka di dunia ini hasilnya 1. Yaitu mulai dari angka 1 sampai dengan tidak terhingga, kemudian dijumlahkan berdasarkan deret angka dicari akar bilangannya, lalu dikelompokkan, terus didapatkan angka yang selalu muncul kemudian dijumlahkan lalu dicari akar bilangannya, terakhir akan menghasilkan angka 1 . Seperti yang dirangkum dalam bagan berikut yang menggambarkan prosedur logika mulai dari angka tak berhingga sampai menjadi tinggal angka satu.

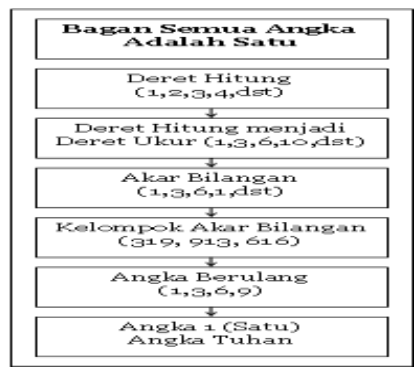

Gambar 2. Bagan Angka

Bahkan bila pohon dijadikan pena, maupun lautan dijadikan tinta untuk menulis semua angka yang terpanjang di jagat raya ini, kesemuanya sedang dan tetap sampai kapan pun berujung pada keEsaan Sang Pencipta, semua angka beriman pada Tuhan yang 1 .

Setelah mengetahui bahwa semua angka sampai tak berhingga secara logika matematika dapat dibuktikan ternyata memiliki hasil yaitu 1 (satu). Karena angka satu ini selalu dan pasti menunjuk kepada Sang Pencipta, maka sebagai umat Islam wajib untuk merujuk bukti ini pada Sang Pencipta pula dengan mengacu pada firman-Nya.

Ada dua ayat yang menyatakan adanya usaha manusia untuk menyusun tulisan sampai tak berhingga tetap tidak cukup untuk menyelesaikan kalimat Tuhan.

Ayat Pertama.

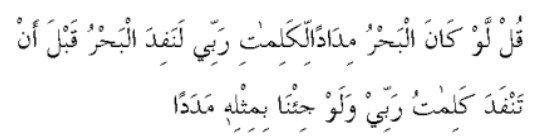

Katakanlah: "Kalau sekiranya lautan menjadi tinta untuk (menulis) kalimat-kalimat Rabbku, sungguh habislah lautan itu sebelum habis (ditulis) kalimat-kalimat Rabbku, meskipun Kami 
datangkan tambahan sebanyak itu (pula)" (QS. Al-Kahfi [18]: 109).

Terbuktilah bahwa walaupun angka ditulis sampai lautan habispun tetap tidak akan bisa menyelesaikan penulisan angka tak berhingga. Tidak sampai sini saja, Allah juga memberikan makna yang tersembunyi dari surat dan ayat ini, untuk meyakinkan bahwa betul kalau angka ditulis sampai berapa pun adalah milik Allah.

Pada penjabaran sebelumnya ada empat angka yang merupakan angka yang selalu muncul pada akar bilangan penjumlahan dari nomor urut 1 sampai tak berhingga, yaitu:

\section{9}

Bila dipisahkan tiga angka pertama dengan angka terakhir dari empat angka ini, akan terlihat pemisahannya di bawah ini. Kemudian surat dan ayat di atas disusun sesuai dengan spasi keempat angka ini, maka terlihat persamaan aritmetika sebagai berikut:

$\begin{array}{llllll}1 & 3 & 6 & & 9 & \text { (Baris Pertama) } \\ 1 & 8 & 1 & 0 & 9 & \text { (Baris Kedua) }\end{array}$

Bahwa jumlah dari angka dari baris pertama di atas 1,3,6 adalah $(1+3+6)$ sama dengan 10 (sepuluh). Begitu juga dengan baris kedua yang merupakan penjabaran dari surat 18 dan ayat 109 menjadi angka 18109. Bila angka sebelah kiri nol (0) yaitu $1,8,1$ dijumlahkan $(1+8+1)$ hasilnya adalah 10 (sepuluh). Sehingga surat dan ayat ini menyimpan makna bahwa memang ada empat angka yang merupakan akar bilangan dari semua akumulasi angka tak berhingga, yang walaupun semua lautan dijadikan tinta untuk menulis akan habislah lautan itu sebelum menyelesaikan angka-angka untuk mencapai definisi tak berhingga.
Jika akar bilangan 1,3,6,9 adalah satu maka begitu juga dengan angka 1,8,1,0,9 akan memiliki akar bilangan yaitu satu, yang didapat dari $1+8+1+0+9$ $=19$ kemudian akar bilangan dari 19 adalah 1 dimana $1+9=10$ dan $1+0=1$.

Ayat Kedua

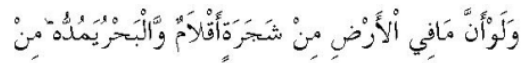

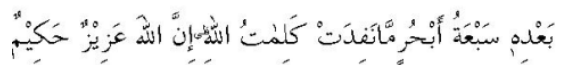

Dan seandainya pohon-pohon di bumi menjadi pena dan laut (menjadi tinta), ditambahkan kepadanya tujuh laut (lagi) sesudah (kering) nya, niscaya tidak akan habis-habisnya (dituliskan) kalimat Allah. Sesungguhnya Allah Maha Perkasa lagi Maha Bijaksana (QS. Luqman [31]: 27).

Ayat ini juga menjelaskan tentang penulisan yang tidak akan selesai untuk menyempurnakan hasil tulisan, dalam hal ini tidak akan selesainya penulisan angka untuk mencapai bilangan tak berhingga.

Selain dari empat angka yang berulang seperti diuraikan dalam ayat pertama, maka ayat ini menyimpan makna adanya pola berulang dari akumulasi angka 1 sampai tak berhingga seperti yang telah diterangkan pada awal bab ini, yaitu:

\section{$319913 \quad 616$}

Dimana, angka 616 didapatkan dari penjumlahan 319 dan 913 dengan memasukkan angka pembagi dua. Dimana, angka 913 merupakan angka kebalikan dari angka 319. Sehingga, didapat bahwa angka utama dari tiga kelompok angka di atas adalah 3, 1, dan 9. Selanjutnya bila kembalikan pada surat dan ayat kedua ini, akan terlihat bentuk persamaan artimetika sebagai berikut:

$$
\begin{array}{llll}
\text { Angka utama } & 3 & 1 & 9
\end{array}
$$


$\begin{array}{lllll}\text { Surat ayat, kedua } & 3 & 1 & 2 & 7\end{array}$ Angka utama menunjuk pada bilangan 31 dan 9, yang memiliki persamaan dengan surat dan ayat kedua. Lihat baris kedua ini, ada angka 31 dan $27(2+7=9)$, yang berarti sama dengan angka utama yang dimaksud yaitu 31 dan 9 .

Jika angka utama memiliki akar bilangan 4 yang merupakan penjumlahan dari $3+1+9=13$ dan $1+3=4$, maka surat dan ayat kedua ini juga memiliki akar bilangan 4 dari penjumlah angka surat dan ayat yaitu $3+1+2+7=13$ dan $1+3=4$.

Maka terbukti bahwa memang surat dan ayat ini hendak menjelaskan bahwa penulisan yang dibantu oleh pohon pena dan laut tintapun tidak akan cukup untuk menyelesaikan tulisan angka sampai tak berhingga itu.

Ada satu ayat lagi yang memberikan hasil akhir berupa akar bilangannya adalah empat dari penjumlahan surat dan ayat di dalamnya. Tetapi makna ayat di bawah ini selain memiliki nilai tersembunyi dari nomor surat dan ayatnya, juga memiliki kaitan yang erat dengan bab sebelumnya berupa tanda tangan Tuhan. Sehingga bisa dicermati arti dari ayat ini secara harfiah yang berkenaan dengan tangan Tuhan dan juga nomor surat ayat dari jumlah akar bilangannya yang menunjukkan persamaan dengan kajian angka pada bab ini.

Ayat berikut memiliki akar bilangan 4 dari penjumlahan surat $48(4+8=12)$ dan ayat $10 \quad(1+0=1)$. Sehingga akar bilangannya adalah 4 dari $12+1=13$ dan $1+3=4$. Apakah ayat ini ada hubungannya dengan sinlammim? Yang pasti ayat ini juga menyimpan 1001 macam makna, mungkin perlu generasi berikutnya lagi untuk membuktikan bahwa ayat ini memang berhubungan erat dengan keberadaan tangan manusia itu sendiri.

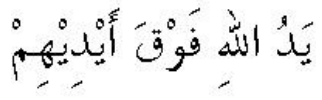

"Tangan Allah di atas tangan mereka" (QS. Al-Fath [48]: 10)

Berdasarkan data matematis yang diambil dengan update terbaru, dengan mewabahnya virus Corona yang menyerang kesehatan umat manusia mengakibatkan ketidaksabilan dalam bidang ekonomi suatu negara hingga pada ekonomi global. Ketidakstabilan ekonomi ini bukan hanya permasalahan biasa yang dapat di selesaikan dengan cepat. Permasalahan ekonomi meliputi tenaga kerja, GDP dan harga pasar. Selain itu COVID-19 ini juga berdampak kepada laju pertumbuhan penduduk dunia yang perlahan-lahan menurun.

Upaya yang ditujukan dalam mengurangi penyebaran covid 19 dan dampak pada bidang ekonomi lainnya yaitu perlu adanya pertimbangan untuk menetapkan kebijakan karena pada saat ini sumbernya tidak dapat di prediksi untuk ekonomi dunia. Kebijakan yang telah diambil dunia tersebut terdiri dari kerjasama antar negara maupun kebijakan di dalam negara itu sendiri.

\section{KESIMPULAN}

Deret hitung bilangan membentuk deret ukur aritmatika yang semakin besar jumlahnya. Bilangan dijumlahkan dalam formasi tangga dengan deret $1+2+3+4+5$ dan seterusnya sampai tdak berhingga. Akumulasi Triangular Numbers menyimpan pengulangan himpunan bilangan dalam digital root. Akar 
bilangan 319, 913, 616 merupakan tiga kelompok bilangan yang memiliki similaritas dengan refleksivitas dari hahslm 7 pada himpunan bilangan 616 berupa representasi 1 dan 6 . Refleksivitas rumus $\mathrm{H}$ pada 2319 tercermin pada dua himpunan bilangan 319 dan 913, Dynivitas digital root pada Triangular Numbers sesuai dengan Quran Surat AlHijr [15]: 87 yang berisi Tujuh dan Quran, berupa bilangan 7 dan 2319 dari faktorisasi 114 surat. Quran dapat dijadikan solusi dalam era ekonomi Covid.

\section{DAFTAR PUSTAKA}

Adiga, C., Surekha, M. S., \& Vanitha, A. (2015). Hurwitz Type Results for Sum of Two Triangular Numbers. $J$. Ana. Num. Theor, 3, 133-135.

Ankiewicz, A., \& Akhmediev, N. (2017). Multi-rogue waves and triangular numbers. Rom. Rep. Phys, 69, 104.

Arfah, A., Olilingo, F. Z., Syaifuddin, S., Dahliah, D., Nurmiati, N., \& Putra, A. H. P. K. (2020). Economics During Global Recession: ShariaEconomics as a Post COVID-19 Agenda. The Journal of Asian Finance, Economics, and Business, 7(11), 1077-1085.

Asma'Munifatussa'idah, K. S. (2020). Indonesia Monetary Policy During COVID-19 Outbreak: In Islamic Economic Perspective.

Aziz, RM. (2015). Teori H dalam Islam Sebagai Wahyu dan Turats. Jurnal UIN Syarif Hidayatullah.

Aziz, RM. (2006). Jejak Islam Yang Hilang, Sinlammim, Jakarta. Http://www.tokogunungagung.co.id

Aziz, RM. (2012). Sinlamim: Kode Tuhan, Esa Alam, Jakarta. Http://www.tokogunungagung.co.id
Aziz, RM. (2008). The Mistery Of Digital Root Based On Sinlammim Method. Proceeding. Institut Teknologi Bandung (ITB). Bandung, Indonesia.

Aziz, RM. (2008). The Mistery Of Digital Root Based On Sinlammim Method. Proceeding. Institut Teknologi Bandung (ITB). Bandung, Indonesia.

Aziz, RM. (2008). The Root Of Mathematics And Science Is level Compared With Religious Thinking. Proceeding. State Islamic University (UIN) Jakarta, Indonesia.

Aziz, RM. (2008). The Root Of Mathematics And Science Is level Compared With Religious Thinking. Proceeding. State Islamic University (UIN) Jakarta, Indonesia.

Baker, J. O., Martí, G., Braunstein, R., Whitehead, A. L., \& Yukich, G. (2020). Religion in the age of social distancing: how COVID.

Balamurugan, P., \& Gnanam, A. (2018). Pattern classification of continued fractions with triangular number as base. International journal of pure and applied mathematics, 119(15), 3413-3418.

Berana, P. J., Montalbo, J., \& Magpantay, D. (2015). On triangular and trapezoidal numbers. Asia Pacific Journal of Multidisciplinary Research, 3(4), 76-81.

Canadas, A. M., \& Angarita, M. A. O. (2011). On sums of three squares and compositions into squares and triangular numbers. JP Journal of Algebra, Number Theory and Applications, 23(1), 25-59.

Castillo, R. C. (2015). On the sum of corresponding factorials and triangular numbers: Some preliminary results. Asia Pacific 
Journal of Multidisciplinary Research, 3(4), 5-11.

Castillo, R. C. (2015). Recurrence relations and generating functions of the sequence of sums of corresponding factorials and triangular numbers. Asia Pacific Journal of Multidisciplinary Research, 3(4), 165-169.

Castillo, R. C. (2015). Sums of two triangulars and of two squares associated with sum of corresponding factorial and triangular number. Asia Pacific Journal of Multidisciplinary Research, 3(4), 5-11.

Castillo, R. C. (2016). A survey on triangular number, factorial and some associated numbers. Indian Journal of Science and Technology, 9(41), 1-7.

Chandrawat, R. K., \& Joshi, V. (2020, May). Profit Optimization of products at different selling prices with fuzzy linear programming problem using situational based fuzzy triangular numbers. Journal of Physics: Conference Series, Vol. 1531, No. 1, p. 012085. IOP Publishing.

Chen, Y. G., \& Fang, J. H. (2007). Triangular numbers in geometric progression. Integers: Electronic Journal of Combinatorial Number Theory, 7, A19.

Coccia, M. (2021). The relation between length of lockdown, numbers of infected people and deaths of Covid-19, and economic growth of countries: Lessons learned to cope with future pandemics similar to Covid-19 and to constrain the deterioration of economic system. Science of The Total Environment, $775,145801$.

De Mestre, N. (2014). Triangular numbers. Australian Mathematics Teacher, 70(3), 14.
Dodurka, M. F., Sahin, A., Yesil, E., \& Urbas, L. (2015, August). Learning of FCMs with causal links represented via fuzzy triangular numbers. IEEE International Conference on Fuzzy Systems (FUZZ-IEEE), pp. 1-8. IEEE.

Fu, R., Yang, H., \& Wu, J. (2018, April). An equation involving the Smarandache primitive function and triangular numbers. AIP Conference Proceedings, Vol. 1955, No. 1, p. 040085. AIP Publishing LLC.

García-Sosa, A. T., \& Maran, U. (2014). Improving the use of ranking in virtual screening against HIV-1 integrase with triangular numbers and including ligand profiling with Antitargets. Journal of chemical information and modeling, 54(11), 3172-3185.

Gumel, A. B., Iboi, E. A., Ngonghala, C. N., \& Elbasha, E. H. (2021). A primer on using mathematics to understand COVID-19 dynamics: Modeling, analysis and simulations. Infectious Disease Modelling, 6, 148-168.

Hassan, M. K., Rabbani, M. R., \& Ali, M. A. M. (2020). Challenges for the Islamic Finance and banking in post COVID era and the role of Fintech. Journal of Economic Cooperation \& Development, 41(3), 93-116.

Keskin, R., \& Karaatly, O. (2012). Some new properties of balancing numbers and square triangular numbers. Journal of Integer Sequences, 15(1), 1-13.

Kniesner, T. J., \& Sullivan, R. (2020). The forgotten numbers: A closer look at COVID-19 non-fatal valuations. Journal of Risk and Uncertainty, 61(2), 155-176.

Li, L. P., \& Fan, G. B. (2014). Fuzzy MADM with triangular numbers for project investment model based on left and right scores. Research 
Journal of Applied Sciences, Engineering and Technology, 7(13), 2793-2797.

Nickerson, A., \& Lemma, M. (2021). Our Brief Journey with properties and patterns of Triangular Numbers. GPH-International Journal of Mathematics, 4(01), 11-22.

Nicola, M., Alsafi, Z., Sohrabi, C., Kerwan, A., Al-Jabir, A., Iosifidis, C., ... \& Agha, R. (2020). The socio-economic implications of the coronavirus and COVID-19 pandemic: a review. International journal of surgery.

Panaoura, R. (2021). Parental Involvement in Children's Mathematics Learning Before and During the Period of the COVID19. Social Education Research, 6574.

Peng, J. (2019). The linear combination of two triangular numbers is a perfect square. Notes on Number Theory and Discrete Mathematics, 25(3), 112.

Pitaloka, H., Al Umar, A. U. A., Hartati, E. R., \& Fitria, D. (2020). The economic impact of the COVID-19 outbreak: Evidence from Indonesia. Jurnal Inovasi Ekonomi, 5(02).

Sun, Z. H. (2019). Ramanujan's theta functions and sums of triangular numbers. International Journal of Number Theory, 15(05), 969-989.

Sun, Z. H. (2019). The number of representations of $\mathrm{n}$ as a linear combination of triangular numbers. International Journal of Number Theory, 15(06), 1191-1218.

Sun, Z. H. (2020). Transformation formulas for the number of representations of $(\mathrm{n} \backslash)$ by linear combinations of four triangular numbers. Bulletin of the Australian Mathematical Society, 102(1).

Tekcan, A. (2019). Almost balancing, triangular and square triangular numbers. Notes on Number Theory and Discrete Maths, 25(1), 108-121.

Wang, M., \& Sun, Z. H. (2016). On the number of representations of $n$ as a linear combination of four triangular numbers. International Journal of Number Theory, 12(06), 1641-1662.

Wang, M., \& Sun, Z. H. (2017). On the number of representations of $\mathrm{n}$ as a linear combination of four triangular numbers II. International Journal of Number Theory, 13(03), 593-617.

Wibisono, M. Y., Truna, D. S., \& Rahman, M. T. (2021). Turning religion from cause to reducer of panic during the COVID-19 pandemic. HTS Teologiese Studies/Theological Studies, 77(4), 1-8.

Xia, E. X., \& Yan, Z. (2019). Proofs of some conjectures of Sun on the relations between sums of squares and sums of triangular numbers. International Journal of Number Theory, 15(01), 189-212.

Yezli, S., \& Khan, A. (2020). COVID-19 social distancing in the Kingdom of Saudi Arabia: Bold measures in the face of political, economic, social and religious challenges. Travel medicine and infectious disease, 37 , 101692. 
| Jurnal PRIMATIKA, Volume 10, Nomor 2, Desember 2021

92 Enkripsi 472319 HAHSLM Dalam Bilangan Segitiga Di Era Ekonomi Covid R Mochamad A 